\title{
FGF1 Gene Fusion Positive
}

National Cancer Institute

\section{Source}

National Cancer Institute. FGF1 Gene Fusion Positive. NCI Thesaurus. Code C148109.

An indication that a FGF1 fusion gene has been detected in a sample. 